\title{
考古地磁気および第四紀古地磁気研究の最近の動向
}

広岡公夫*

\section{Recent Trend in Archaeomagnetic and Palaeomagnetic Studies in Quaternary Research}

\section{Kimio HIrookA*}

はじめに

岩石や燒土に残されている自然残留磁気(Natural Remanent Magnetization 略して N. R. M.) を用いて過 去の地磁気の変化を調べることができる. 人間が生活し ていた遺跡の焼土からは，その当時の地磁気，すなわち， 考古地磁気 (Archaeomagnetism)の変化を読みとること ができるし，すっと前の地質時代にできた岩石からは， 地質時代の地磁気 (古地磁気, Palaeomagnetism) の变 遷がとらえられる。一般に考古地磁気学とは考古学で报 っている過去数千年間の地磁気变動を求め, 古地磁気学
は地質時代の地磁気の逆転や大陸移動などを明らかにす るものであるとされてきたが，最近，約 3 万年前の遺跡 の焼土の測定から逆転が発見されたり (BARBETTI and

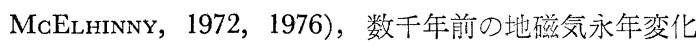
が湖底堆積物ふら求められる（THOMPsON，1973）など, 新しい研究成果が相次ぎ発表され, 考古地磁気と古地磁 気の境界がなくなってきた。これは, 第四紀の地磁気学 にとっては喜こばしいことで，今まで，空白になってい た洪積世末から沖積世前半にかけて地磁気恋動が明らか にされるとともに，双方から得られた結果のクロスチ土 ックが可能な状態になってきたのである.

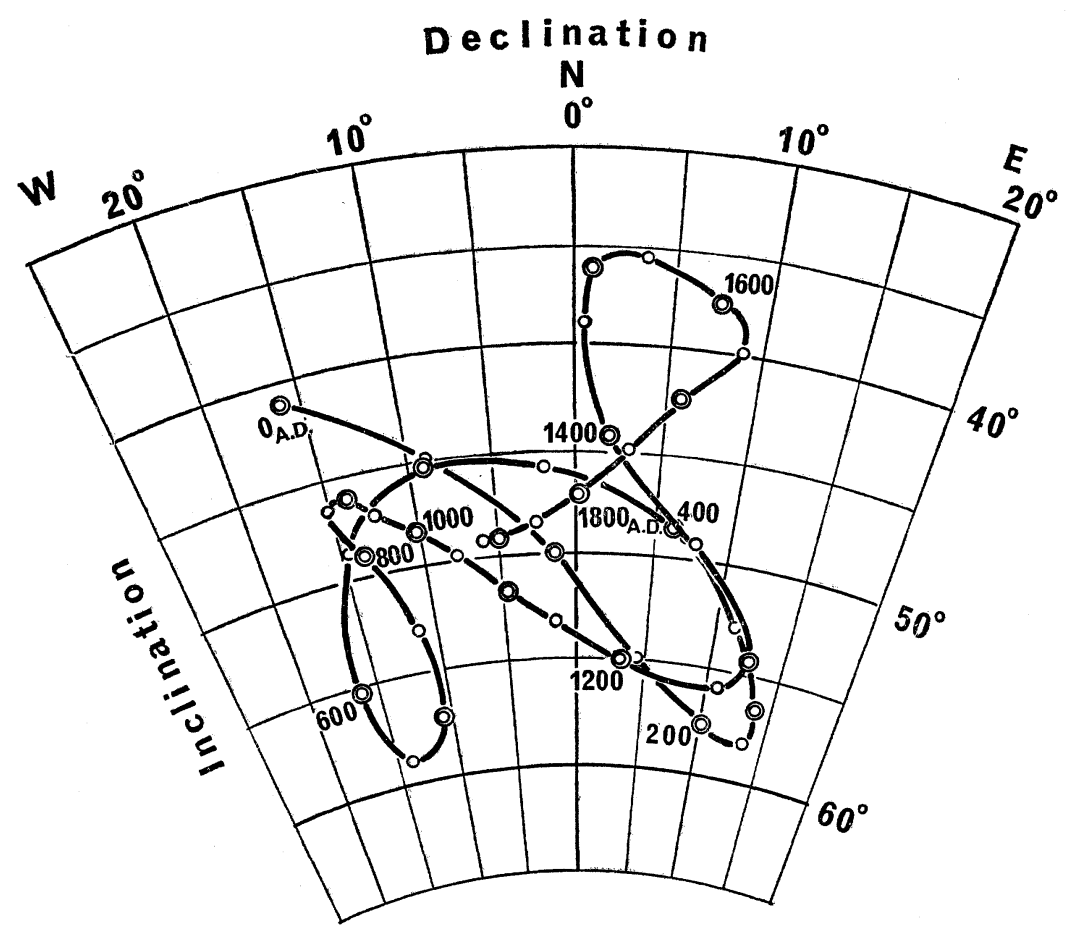

四 1 西南日本の考古遺跡焼土の測定から求められた過去 2000 年間の地磁気永年孪化 


\section{考古地磁気学}

MERCANTON (1918) による青銅器時代の土器の磁化測 定にはじまる考古地磁気の研究は，最近もヨーロッパ， 米国, ソ連および日本の研究者によって着実に進められ ている.ただ考古地磁気研究者は慎重な人が多くて，沢 山のデータを持占，国際学会での口頭の発表もしていな がら論交として発表していない例が多い，考古地磁気の 永年変化に関して，偏角，伏角の両方の測定が，英国 (ArtKen et al., 1964), フランス (Thellier and TheLlIER, 1959), ブルガリア(KovacheVA and NAGHEVAKalcheva, 1975), 米国 (DuBors and Watanabe, 1965) および日本（WATANABE，1959; KaWAI et al., 1965 ; HrRoOKA，1971) で積極的に行われている. 図1 に西南日本の遺跡の測定から求めた過去 2000 年間の偏 角・伏角の変化を示しておく. この他に伏角変化のみ についての研究はソ連 (BuRLATSKAYA et al., 1965) や 中国 (鄧，李，1965）でも行われている.また地磁気強 度の永年変化に関する研究があり, 上記の地域（THEL_ Lier and Thellier, 1959 ; Bucha et al., 1970 ; SasaJima and Maenaka, 1966 ; Kitazawa, 1970) 以外に インド (Athavale, 1966), ペルー (Kitazawa and KoBAYASH， 1968）で行われている.このように過去 2000 年間程について相当詳しく地磁気の变化が把元ら れるようになった。そして，永年変化の主要因は非双極 子磁場か，主双極子磁場の变動かが大きな䦗題としてク ローズアップされてきた. 従来, 通説として偏角・伏角 の永年変化は，非双極子磁場の西方移動が原因であると 考えられてきた(VESTINE et al., 1947 ; BUllard et al., 1950 ; YUKUTAKE，1968)，地磁気の観測記録の分析に用 いられている球面調和解析を使光ば，考古地磁気永年变 化が双極子磁場によるものか非双極子磁場によるものか がはっきりするのであるが, 残念ながら, 球面調和解析 を適用するには，まだあまりにも考古地磁気データーが 少なすぎる。しかし，各地の考古地磁気の測定結果を古 地磁気で，よく用いる方法で双極子近似で見かけの磁極 (Virtual Geomagnetic Pole) 劣求めて比べてタると, 1500 年という短い周期で地磁気双極子が变動してお り，それぶ永年变化の主要であるように見えるのである (KAWAI and HirookA, 1967 ; HirookA, 1971 ; 広 岡, 1972).

最近のむう一つのトピックスは地球磁場強度の永年変 化と気候変動の相関についてであるが，これは，考古時 代にかぎらず 氷河期以前までさかのぼるので後でのべ
る.

\section{第四紀古地磁気学}

第四紀の古地磁気の研究は, 古い地質時代よりも詳し く地磁気の変化を追跡しうるし, また, 考古地磁気より も長い期間にわたって調べることができるという点で非 常に重要である.とくに地磁気の逆転の過程や, その前 後の永年変化の様子が明らかにされると, 逆転のメカ二 ズム解明に大きく寄与することが出来る.

最近，多くの海底あるいは湖底の堆積物の磁気測定が 進められた結果，時間的に連続に地磁気変化が追跡され て，多くの新しい事実が明らかになった，例えば，今ま で地磁気の逆転がないとされていた Brunhes 正帯磁期 にいくつかの逆転が報告されていて，主なものをあげる と，1.25 万年前頃 (MÖRNER et al., 1971)，1.8 万年 前頃 (Nakajima et al., 1973 ; Noltinier and ColinVAUx，1976)，3 万年前頃(BARBetTi and MaElhinNy, 1976)，11. 万年前頃（SMITH and Foster，1969） およ び 17 万年前頃と 29 万年前(KAWAI et al., 1972) と なる、これらの報告の中で, 琵琶湖の湖底ボーリングの $200 \mathrm{~m}$ の長さのコアの測定は, 約 50 万年前までの地磁 気を連続的に追えるという点で特に注目に值する.コア から $5 \mathrm{~m}$ 間隔でサンプルをとり測定した結果 1.8 万年, 11 万年(Blake Event), 17 万年 (Biwa Event I), 29 万年(Biwa Event II) の Event が確認されている.こ のコアについては， $2 \mathrm{~cm}$ 立方の大きさの試料学 $200 \mathrm{~m}$ の上から下をで連続してとるという大変爫力のいる測定 が現在もつづけられており，すでに上から $60 \mathrm{~m}$ 分まで の測定が済んでいる(KAWAI et al., 1975).これによる と深さ $55 \mathrm{~m}$ 前後に Blake Event がはっきり検出され ており，その前の $35 \mathrm{~m}$ と $26 \mathrm{~m}$ 付近にも地磁気が非常 に不安定な時期のあったことがわかる（図2），後者は 4.9 万年前頃のことである (YASKAWA et al. 1973).

堆積速度が大きく，かつ堆積が休みなくつづいたとこ ろから古地磁気試料を連続的にとると地磁気の短期間の 变動も把えることができ, 従来のような火山岩中心の研 究では検出できなかった細かい古地磁気変遷它追うこと ができる、逆転する途中では，試料の磁化強度も小さ く,ぞうも地球磁場の強度そのものが小さかったと推定 される. 海底堆積物の古地磁気測定と酸素同位体による 古温度測定の結果を比べると, 磁化強度の小さい時は古 海水温度が暖かかったらしいという報告もある(WOLLIN et al., 1971) が KAWAI 他 (1975) は琵琶湖のコアの花粉 分析，炭素同位体の測定結果と比べたところ地磁気強度 


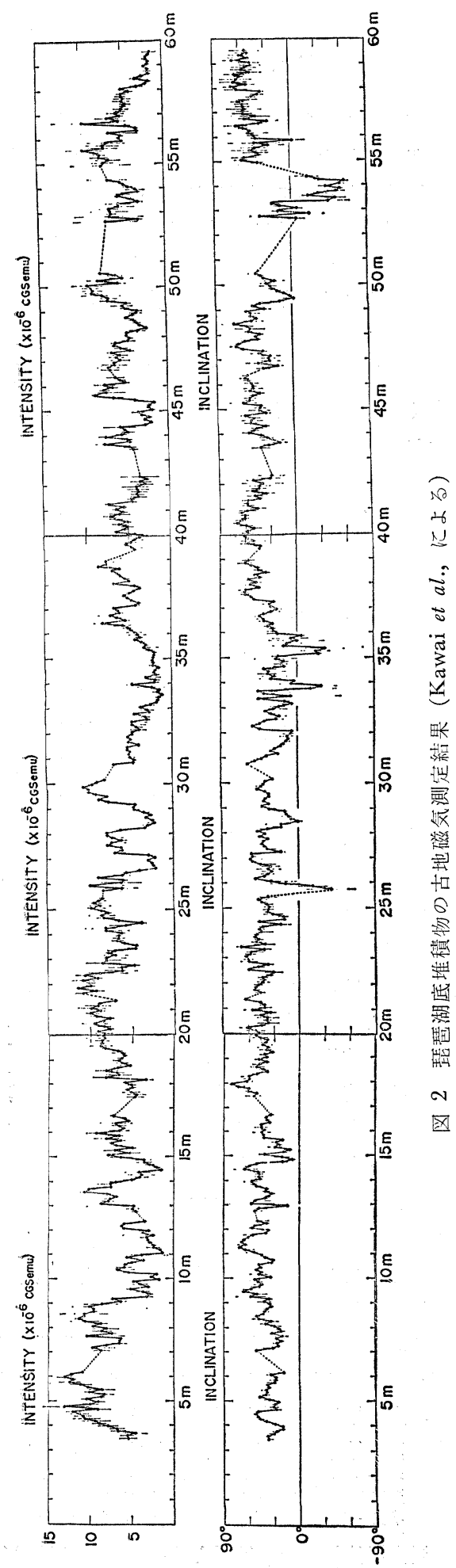

の減少と気候の寒冷化とは強い相関があり, 地磁気強度 の変化は気侯変動に大きな影響を持っていると考えてい る. 地磁気变動, 火山活動, 気候变動の関係の解明は, 第四紀学の今後の大きな課題となるであらう.

第四紀末に打汀る地磁気の逆転や excursion がグロー バルな現象か否かということも大問題である. Brunhes 正帯磁期に発見された多くの event のうち 11 万年前頃 の Blake Event は世界各地から報告されているのでグ ローバルな逆転である可能性が高いが，他の例光ば Gothenburg Event (1.25 万年前), 琵琶湖之 Imuruk 湖 の excursion (1.8 万年前 Mungo Event ( 3 万年前) や Bonhommet (1970) の発見した Laschamp Event $(0.8$ 〜3万年前頃）等がはたして抒互いに違うものなのかど うかは年代推定の精度を考光るとはっきりいえないし， これらのすべてがグローバルなものかどうかも不明であ る. 双極子磁場が弱った時に非双極子磁場が大きく影響 して局所的に excursionが起ったように見えているのか も知れない，年代決定の精度をあげ，更により多くのデ ーターを蓄積すれば解決するであるう。いずれにして も，1〜3 万年前頃にも地磁気の不安定な時期があった と思わ机る。

\section{参考 文 献}

Aithen, M. J., Harold, M.R. and Weaver, G. H. (1964) Some archaeomagnetic evidence concerning the secular variation in Britain. Nature, 201, 659 -660 .

Athavale, R. N. (1956) Intensity of Geomagnetic field in India over the past 4090 years. Nature, 210, 1310-1312.

Barbetti, M.F. and MaElhinny, M. W. (1972) Evidence of a geomagnetic excursion $30,000 \mathrm{yr}$ B. P. Nature, 239, 327-330.

Barbetti, M.F. and MaElhinny, M.W. (1976) The Lake Mungo geomagnetic excursion. Phil. Trans. Roy. Soc. London, Math. Phys. Sci., 281, 515-542.

Bonhommet, N. (1970) Discovery of new event in the Brunhes period at Laschamp (France). in palaeogeophysics, Academic Press, 159-163

Bucha, V., Taylor, R.E., Berger, R. and Haury, E.W. (1970) Geomagnetic intensity: changes during the past 3000 years in the western hemisphere. Science, 168, 111-114.

Bullard, E. G., Freedman, G., Gellman, H. and Nixon, J. (1950) The westward drift of the earth's magnetic field. Phil. Trans. Roy. Soc. London, A, 243, 67-92.

Burlatikaya, S.P., Nechaeva, T.B. and Petrova, G. N. (1965) The westward drift of the secular variation of magnetic inclination and variations of 
the earth's magnetic moment according to "archeomagnetic" data. Akad. Nauk. SSSR. Isv. Geophys. Ser., 31-42.

DuBors, R. L. and Watanabe, N.(1965) Preliminary results of investigations made to study the use of Indian pottery to determine the paleointensity of the geomagnetie field for United States 600-1400 A.D. J. Geomag. Geoelec., 17, 417-425.

Hirooka, K. (1971) Archaeomagnetic study for the past 2000 years in Southwest Japan. Mem. Fac. Sci., Kyoto Univ., Ser. Geol. Mineral, 38, 167-207.

広岡公夫 (1972) 西南日本の地磁気永年変化. 海洋科学, 4, 555-563.

Kawar, N. and Hirooka, K. (1967) Wobbling motion of the geomagnetic dipole field in historic time during these 2000 years. J. Geomag. Geoelec., 19, $217-227$.

Kawai, N., Hirooka, K., Sasajima, S., Yaskawa, K, Ito, H. and Kume, S. (1965) Archaeomagnetie studies in Southwestern Japan. Ann. Geophys., 21, $574-577$.

Kawai, N., Yaskawa, K., Nakajima, T., Torit, M. and Horie, S. (1972) Oscillating geomagnetic field with a recurring reversal discovered from Lake Biwa. Proc. Japan Acad., 48, 186-190.

Kawai, N., Yaskawa, K., Nakajima, T., Torir, M. and Natsukara, N. (1975) Voice of Geomagnetism from Lake Biwa. Paleolimnology of Lake Biwa and the Japanese Pleistocene, 3, 143-160.

KitazawA, K. (1970) Intensity of the geomagnetic field in Japan for the past 10,000 years. $J$. Geophys. Res., 75, 7403-7411.

Kitazawa, K. and Kobayashi, K. (1968) Intensity variation of the geomagnetic field during the past 4, 000 years in South America. J. Geomag. Geoelec., 20, 7-19.

Kovagheva, M. G. and Nagheva-Kalgheva, V. B. (1975) First results of archaeomagnetic investigation of prehistoric site in Bulgaria. C. R. Acad. Bulgare Sci., 28, 919-921.

Mercanton, P.L. (1918) État magnétique de quelques terres cuites préhistoriques. C. R. Acad. Sci. Paris, 166, 681-682.

Mörner, A. N., Lanser, J. P. and Hosper, J. (1971) Late Weichselian palaeomagnetic reversals. Nature,
Phys. Sci., 234, 173-174.

Nakajima, T., Yaskawa, K., Natuhara, N. and KaWAI, N. (1973) Very short period geomagnetic excursion 18,000 yr B.P. Nature, Phys. Sci., 244, 8-10.

Noltimier, H. G. and Colinvaux, P.A. (1976) Geomagnetic excursion from Imuruk Lake, Alaska. Nature, 259, 197-200.

鄧興恵 - 李東節 (1965) 北京地区史期地磁場及其変化的 研究. 地球物理学報, 14, 181-195。

Sasajima, S. and Maenaka, K. (1966) Intensity studies of the archaeo-secular variation in West Japan, with special reference to the hypothesis of the dipole axis rotation. Mem. Coll. Sci. Univ. Kyoto, Ser. $B, 33,53-67$.

Smith, J. D. and Foster J. H. (1969) Geomagnetic reversal in Brunhes nömal polarity epoch. Science, 163, 563-567.

Thellier, E. and Thellier, O. (1959) Sur l'intensité du champ magnétique terrestre dans le passé historique et géologique. Ann. Géophys., 15, 285376.

Thompson, R. (1973) Palaeolimnology and Palaeomagnetism. Nature, 242, 182-184.

Vestine, E. H., LaPorte, L., Gooper, C., Lange, I. and Hendrix, W. C. (1947) Description of the earth's, mainmagnetic field and its secular change, 1905-1945. Carnegie Inst. Washington Publ., no. $578,1-532$.

Watanabe, N. (1959) The direction of remanent magnetism of baked earth and its application of chronology for anthropology and archaeology in Japan. J. Fac. Sci., Univ. Tokyo, Sec. II, 2, 1188.

Wollin, G., ERrason, D.B. and Ryan, W.B.F.(1971) Variation in magnetic intensity and climatic changes. Nature, 232, 549-551.

Yaskawa, K., Nakajima, T., Kawai, N., Torir, M. Natsuhara, N. and Horie, S. (1973) Palaeomagnetism of a core from Lake Biwa ( I ). J. Geomag. Geoelec., 25, 447-474.

Yukutake, T. (1968) Synthesis of the non-dipoecomponents of the earth's magnetic field from sphel rical harmonic coefficients, Bull. Earthqu. Res. Inst., 46, $385-403$. 